\title{
RURAL HOUSEHOLDS' FOOD INSECURITY AND COPING STRATEGIES DURING COVID-19 PANDEMIC IN ENUGU STATE, NIGERIA
}

\author{
Okidim, I. A ${ }^{1}$., Egwue, L. O²*, Ekine, D. I ${ }^{1}$, Chukuigwe, E. C. \\ ${ }^{1}$ Department of Agricultural and Applied Economics, Rivers State University, PMB 5080, Port Harcourt, \\ Nigeria \\ ${ }^{2}$ Department of Agricultural Economics, University of Nigeria Nsukka, Enugu State, Nigeria \\ *Corresponding author email: lyndaegwue@gmail.com
}

Citation: Okidim, I.A., Egwue, L.O., Ekine, D.I., Chukuigwe, E.C, 2021. Rural households' food insecurity and coping strategies during covid-19 pandemic in Enugu state, Nigeria. J. Asian Rur. Stud. 5(2): 126-134

\begin{abstract}
Food insecurity is a challenge in developing countries, especially in the rural areas of Nigeria. It remains a global challenge and continues to be a major public policy in Nigeria and other developing nations. Despite these, COVID-19 set in and posed a serious threat to food system and security globally. This study, therefore, assessed the level of food security among the rural farming households and how they cope with the situation during the COVID-19 pandemic. Data for the study were collected primarily from 200 farming households with the use of questionnaires and analysed using descriptive statistics, food security index and Likert scale. The findings showed that the level of food insecurity was very high during the pandemic as $69.5 \%$ were food insecure with a high concentration among those with large household size. The widely adopted coping strategies during COVID-19 pandemic among the rural farming households were eating less expensive food $(\bar{x}=2.7)$, reducing rational consumption $(\bar{x}=2.68)$, allowing children to eat first $(\bar{x}=2.56)$, engaging in additional small scale productivity activities $(\bar{x}=2.27)$, skipping meal within a day $(\bar{x}=2.26)$, buying food on credit $(\bar{x}=2.05)$ and borrowing money to buy food $(\bar{x}=2.01)$. The study recommends effective and urgent policy measures which will support rural households' food availability to boost their food security status. Also, enlightenment of the rural households on the important of modern family planning on their food security status is needed.
\end{abstract}

Keywords: Food Insecurity; Coping Strategies; COVID-19; Rural Households; Nigeria

\section{Introduction}

Food insecurity is a challenge in Africa including Nigeria and other developing countries, especially in the rural areas (Mukaila et al., 2020). Globally, many efforts have been channelled to increase food production and quality, yet malnutrition has resulted in the death of many Asia and Africa citizens (Matemilola \& Elegbede, 2017). Thus, challenges in providing enough food is a society problem which requires government interventions to implement food policies to cub the problem of food insecurity (Ali, Majika \& Salman, 2017; Teddu, Ali \& Salman, 2018). Food insecurity remains a global challenge and continues to be a major public policy in Nigeria and other developing nations. Nigeria is faced with the challenge of food insecurity and has been featured among the food deficient nations in the Global Hunger Index (GHI). This is alarming for a country which has natural resources and all it takes to be food sufficient.

Prior to the oil boom in Nigeria, the country was food sufficient and net exporter of agricultural products. This changed when the country focused on oil which lead to the 
neglection of agricultural sector (Mukaila, Falola, \& Omotesho, 2020). Improvement of agricultural sector is thus needed to curb the problem of food insecurity in the nation. Agriculture is, however, one of the most important sectors of the Nigerian economy, employs about $70 \%$ of the labour force and, perhaps most importantly, provide more than 80 per cent of the food needs of the country (NBS, 2012; Obetta et al., 2020). Despites rural people involvement in agriculture, they are most hit with malnutrition, chronic food shortage, erratic food supply, poor quality foods and unbalanced nutrition.

Despite the global challenge of food insecurity and malnutrition, COVID-19 set in which added severely to the challenges. The end of 2019 ushered in the spread of a novel coronavirus (COVID-19) causing respiratory symptoms and disease which was confirmed as an outbreak by the World Health Organization (WHO) in January 2020 (Soma, 2020). The disruptions caused by the COVID-19 pandemic are now threatening the food security of billions of people worldwide (Zurayk, 2020). Indeed, after initial reassurances that COVID-19 posed no concerns to global food security, as the world's silos were well stocked, the tone has now radically reduced (Vos et al., 2020). People are now being warned that global hunger could double due to disruptions caused by COVID19 to the food supply, especially in poor nations and in Africa (De Sousa, 2020). The pandemic has negatively affected each of the four dimensions of food security which are availability, accessibility, utilization, and stability (Zurayk, 2020). It affected the availability of food through transportation restriction, restriction in international trade by some countries and limiting planting and harvesting of crops due to movement restriction (Zurayk, 2020). Households are now adopting food insecurity coping mechanism as a result of the pandemic; these mechanisms limit their food consumption to a few types thereby affecting the utilization of the food. This destabilized the food system in Nigeria and other African nations. Therefore, the current COVID-19 pandemic put a risk to agricultural activities and may put a negative effect on the food security status globally most especially rural areas of developing countries, Nigeria inclusive.

Although several researchers had assessed food security in Nigeria (Omotesho et al., 2006; Babatunde et al., 2007; Babatunde \& Qaim, 2010; Oyebanjo et al., 2013; Obasan et al., 2017; Mukaila et al., 2020). But little has been done on the current situation of food security during COVID-19 and how rural dwellers cope with the challenge. There is thus need to fill this research gap. In view of these, the objectives of this study are to evaluate the food security level of the rural farming households of Enugu State, Nigeria and how they cope with food insecurity during the current COVID-19 pandemic.

The next section of this paper described the data and methodology adopted in this study. This was followed by section three which presents and discussed the findings of the study. The last section concludes and draw policy recommendations from the study.

\section{Method}

\subsection{Study Area}

This study was carried-out in Enugu State, Nigeria. The area is one of the 36 States of Nigeria and lies between latitudes $5^{\circ} 56^{\circ} \mathrm{N}$ and $7^{\circ} 05^{\circ} \mathrm{N}$ of the Equator and longitudes $6^{\circ} 53^{\circ} \mathrm{E}$ and $7^{\circ} 55^{\circ} \mathrm{E}$ of the Greenwich meridian (Enugu State Agricultural Development Programme [ENADEP], 2014; Obetta et al., 2020). The state has 17 local governments areas (LGAs) and occupies a landmass of approximately $8,022.95 \mathrm{~km}^{2}$ with a population of about 3,257,298 (ENADEP, 2016). The state shares boundaries in the East with Ebonyi 
State; in the south with Abia State; in the North with Benue and Kogi States and in the West with Anambra State. The major occupation of the rural people in the area is agriculture and serves as source of livelihood to them.

\subsection{Sampling Techniques}

Respondents were selected using three stage random sampling technique. First stage involved a random selection of five LGAs in the state. In the second stage, two rural farming communities were randomly selected from each LGAs. This gave a total of ten rural farming communities. At the third stage, twenty households were randomly selected from rural communities. Thus, a total of 200 rural households were used for this study.

\subsection{Sources and Method of Data Collection}

Data for this study were collected primarily from 200 rural farming households using questionnaires and interview schedule. The primary data collected contained information on their socio-economic characteristics, amount and types of food consumed by households and food insecurity coping strategies adopted by households during COVID19 pandemic.

\subsection{Method of Data Analysis}

Data collected were analysed using descriptive statistics, food security indices and Likert rating scale. Descriptive statistics such as mean, frequency and percentages were used to describe the socioeconomic features of rural households and present the results.

\subsection{Food Security Indices and Models}

Following Omotesho et al. (2006), Opaluwa et al. (2018) and Mukaila et al. (2020), food security index was used to measure the food security status of the rural households. This method involved the use of a daily minimum recommendation level of $2260 \mathrm{kcal}$ per capita per day by Food and Agriculture Organisation as the food security line. The daily per capita calorie intake was estimated by dividing the estimated daily calorie intake of the household by the household size in adult equivalent using the equivalent male adult scale weights while calorie available in the food consumed was estimated using food nutrient composition. Thus, any rural household that consumed below $2260 \mathrm{kcal}$ per capita was considered food insecure while those that consumed $2260 \mathrm{kcal}$ per adult equivalent or above were considered food secure household.

Food security index $\mathrm{Z}=\frac{\text { Household's daily per capita calorie availability (A) }}{\text { Household's daily per capita calorie requirement (I) }}$

The Headcount ratio (HR) is a measure of food security status and it is defined as

$H R=\frac{M}{N}$

Where,

$\mathrm{M}$ is the total number of the food-insecure

$\mathrm{N}$ is the sample population

Food insecurity gap $\left(\mathrm{FIG}_{\mathrm{i}}\right)$ was used to measures the depth of food insecurity among the rural households. It is expressed as: 
$\mathrm{FIG}_{\mathrm{i}}=\frac{\mathrm{TCR}_{\mathrm{i}}-\mathrm{TCC}_{\mathrm{i}}}{\mathrm{TCR}_{\mathrm{i}}}$

The total food insecurity gap or shortfall index is given as:

$\mathrm{TFIG}=\frac{\sum\left(\mathrm{TCR}_{\mathrm{i}}-\mathrm{TCC}_{\mathrm{i}}\right)}{\mathrm{TCR}_{\mathrm{i}}}$

Square food insecure gap was used to examine the severity of food insecurity among the food insecure household. It is expressed as:

$\mathrm{SFIG}=\frac{\sum\left(\mathrm{FIG}_{\mathrm{i}}\right)^{2}}{\mathrm{M}}$

Where,

$\mathrm{TCC}_{\mathrm{i}}$ is the total calorie consumed by $\mathrm{i}^{\text {th }}$ food insecurity household

$\mathrm{TCR}_{\mathrm{i}}$ is the total calorie requirement for $\mathrm{i}^{\text {th }}$ food insecurity household

$\sum$ is the summation

\subsection{Likert scale}

Likert scale was used to analyse the food insecurity coping strategies adopted by the households during COVID-19 pandemic. It is a psychometric response scale primarily used in questionnaires to obtain participant's preferences or degree of agreement with a statement or set of statements. This has been widely used by researchers (e.g., DeclaroRuedas, 2019; Mukaila et al., 2020) to measure food insecurity coping strategies. In this study, three points Likert scale was constructed ranging from always (3), occasionally (2) and never (1). These three values were added up to get a value of 6 and it was divided by 3 to get the mean value of 2 . The respondent's mean score was obtained on each of the items, all the mean scores equal to or greater than 2 was regarded widely adopted or major coping strategies and any less than 2 was considered less adopted.

\section{Results and Discussion}

\subsection{Socio-economic Characteristics of Rural Households}

Table 1 presents the socioeconomic profile of the rural households. The rural household heads were dominated by male who accounted for $92 \%$ of the household heads. The majority of the rural household heads were above forty years with an average age of 53 years. This suggests they are still within the economic active age. About $94 \%$ were married with an average household size of 7 persons. This suggests a relatively large household size which, however, can be used as cheap family labour for their farming activities.

The level of education among the rural households' heads were relatively low as only $4.5 \%$ had tertiary education. This could affect their productivity as education enhance agricultural production, marketing and management (Obetta et al., 2020; Mukaila et al., 2021). Similarly, level of cooperative membership was low among them as only $17 \%$ belong to the society. This could deny them some benefit such as credit access, enjoyment of economies of scale and relevant information which could be gotten from cooperative society. 
The household heads had an average farming experience of 23 years and could be well experienced Farming experience enable a better decision making regarding combination of inputs and allocation of resources, thus enhance productivity (Akanbi et al., 2020). The rural household heads were operating on a small-scale farming as the majority had below 3 hectares of farmland. Regarding rural household heads annual income, majority had below $\$ 200,000$ (USD 524.59) per annum. Their average annual income was $\$ 171,666$ (USD 450.27).

Table 1. Socio-economic Characteristics of Rural Households

\begin{tabular}{|c|c|c|c|}
\hline Characteristics & Frequency & Percentage & Mean \\
\hline \multicolumn{4}{|c|}{ Gender of the household head } \\
\hline Male & 184 & 92 & \\
\hline Female & 16 & 8 & \\
\hline \multicolumn{4}{|l|}{ Age of household head } \\
\hline Below 40 & 29 & 14.5 & 53 \\
\hline 41 to 50 & 65 & 32.5 & \\
\hline 51 to 60 & 70 & 35 & \\
\hline Above 60 & 36 & 18 & \\
\hline \multicolumn{4}{|l|}{ Marital status } \\
\hline Single & 8 & 4 & \\
\hline Married & 187 & 93.5 & \\
\hline Widow & 5 & 2.5 & \\
\hline \multicolumn{4}{|l|}{ Educational status } \\
\hline No formal education & 25 & 12.5 & \\
\hline Primary education & 98 & 49 & \\
\hline Secondary education & 68 & 34 & \\
\hline Tertiary education & 9 & 4.5 & \\
\hline \multicolumn{4}{|c|}{ Cooperative association } \\
\hline Member & 34 & 17 & \\
\hline Non-member & 166 & 83 & \\
\hline \multicolumn{4}{|c|}{ Household size (Adult equivalent) } \\
\hline Less than 4 & 78 & 39 & 7 \\
\hline 5 to 8 & 101 & 50.5 & \\
\hline Above 8 & 21 & 10.5 & \\
\hline \multicolumn{4}{|c|}{ Farming experience (years) } \\
\hline 1 to 10 & 48 & 24 & 23 \\
\hline 11 to 20 & 56 & 28 & \\
\hline 21 to 30 & 44 & 22 & \\
\hline above 31 & 52 & 26 & \\
\hline \multicolumn{4}{|l|}{ Farm size (ha) } \\
\hline Less than 2 & 89 & 44.5 & 2 \\
\hline 2 to 3 & 76 & 38 & \\
\hline 3 to 4 & 22 & 11 & \\
\hline Above 4 & 13 & 6.5 & \\
\hline \multicolumn{4}{|l|}{ Annual income ( } \\
\hline$<100,000$ & 60 & 30 & 171,666 \\
\hline 100,001 . to 200,000 & 77 & 38.5 & \\
\hline 200,001 to 300,000 & 47 & 23.4 & \\
\hline$>300,000$ & 16 & 8 & \\
\hline
\end{tabular}

Source: Field survey, 2020 


\subsection{Rural Household Food Security Level}

Table 2 presents the results of the food security index. The results revealed that only $30.5 \%$ of the rural households were food secure and fed on an average of 2,535.5 per capita kilo calories per day, thus exceeded the food security line by $12 \%$. While $70.5 \%$ were food insecure, they fed on an average of 1,381.4 kcal per adult equivalent per day, thus they fell short of $39 \%$ of the daily recommended kilocalories. The level of food insecurity among the rural households during COVID-19 pandemic was, however, higher than the food insecurity level of 54.5\% reported by Mukaila et al. (2020). The level of food insecurity was higher among the households with larger size as food insecure households had an average household size of nine persons while food secure households had five persons per household on average. The head count ratio further shows that seven out of every ten persons were food insecure in the rural areas. Square shortfall index or square food insecure gap, which shows food insecurity severity among the food insecure household, was 0.006 . This level of food insecurity was very high which was due to the effect of COVID-19 pandemic on food availability in the rural households as there was movement restrictions in the areas. This implies that food insecurity remains a serious challenge among the rural households of the study area.

Table 2. Results of Household Food Security Indices.

\begin{tabular}{lll}
\hline Food security indices & Food insecure & Food secure \\
\hline Percentage household & 69.5 & 30.5 \\
Head count ratio & 0.7 & 0.3 \\
Square food insecure Gap & 0.006 & \\
Shortfall/surplus index & 0.39 & 0.12 \\
Per capita calorie available per day & 1381.4 & 2535.5
\end{tabular}

Source: Field survey, 2020

\subsection{Food Insecurity Coping Strategies adopted by Rural Households during COVID-19 pandemic}

Table 3 presents the result of Likert type rating used to identify the food insecurity coping mechanisms adopted during the COVID-19 pandemic by the rural households. Eating less expensive food $(\bar{x}=2.7)$ was the most widely adopted and ranked first among the food insecurity coping strategies among rural households. They consumed less expensive which were less preferred to cope with the effect of food insecurity. This suggests that the households purchased less expensive food for them to have enough food in their households. This is in line with the findings of Declaro-Ruedas (2019) and Mukaila et al., (2020) who reported that eating less expensive food was ranked first among the food insecurity coping strategies. Using this strategy could be related to the lower-income status of the rural people and large household size which requires a lot of food to feed them.

Reducing rational consumption $(\bar{x}=2.68)$ by the households was also widely adopted to cope with the problem of food insecurity and was ranked second. To cope with the effect of food insecurity impose by the COVID-19, the rural households reduced their rations to manage the available foodstuff in their households. This conforms with the findings of Agada and Igbokwe (2015), and Mukaila et al., (2020) who reported that households limit their meal portion size to cope with food insecurity. Allowing children 
to eat first $(\bar{x}=2.56)$ was also widely adopted and ranked third among the food insecurity coping mechanisms among rural households. The adults in the household allowed the children to eat first because the children cannot endure starvation.

Engaging in additional small-scale productivity activities $(\bar{x}=2.27)$ was also commonly adopted by rural households during COVID-19 pandemic. The household head engaged in additional small-scale productivity activities such as backyard poultry production, making of garri to boost their economic and food security status. Skipping meal within a day $(\bar{x}=2.26)$ was also widely adopted to cope with the effect of food insecurity. This was common among the adult in the households especially the household heads who sacrificed their meal for their household members. They adopted this mechanism to keep and manage foodstuff available in their households. Buying food on credit $(\bar{x}=2.05)$ was widely used to cope with food insecurity during the COVID-19 pandemic. The household heads purchased food on credit, though at a higher price, in order to feed their households to avoid severe food insecurity problem. Borrowing money to buy food $(\bar{x}=2.01)$ was also commonly adopted by household heads to cope with food insecurity problem.

Mortgaging and sales of domestic assets $(\bar{x}=1.59)$, eating wild fruits $(\bar{x}=1.53)$, eating once a day $(\bar{x}=1.49)$, selling of labour ( $\bar{x}=1.48)$, and picking up left-over food at social functions $(\bar{x}=1.37)$ were not considered a major adopted coping strategy because their mean score was lower than 2.0 which was the cut point to identify the widely used coping strategies. Though some proportion adopted it but more than half of the population did not adopt it.

Engaging in food insecurity coping strategies by almost all rural households implies food shortage and poor access to food among rural households. This is detrimental to their health and nutritional status especially the children and elderly ones who needs adequate and balanced diet for healthy living and to boost their immunity against diseases such as the present COVID-19 pandemic.

Table 3. Food Insecurity Coping Strategies Adopted by Rural Households

\begin{tabular}{|c|c|c|c|c|c|c|}
\hline Coping strategies & $\begin{array}{l}\text { VE } \\
\text { Freq (\%) }\end{array}$ & $\begin{array}{l}\text { E } \\
\text { Freq (\%) }\end{array}$ & $\begin{array}{l}\mathrm{NE} \\
\text { Freq (\%) }\end{array}$ & WS & LM & $\mathrm{R}$ \\
\hline Eating less expensive food & $143(71.5)$ & $54(27)$ & $3(1.5)$ & 540 & 2.70 & 1 \\
\hline Reducing rational consumption & $152(76)$ & $32(16)$ & $16(8)$ & 536 & 2.68 & 2 \\
\hline Allowing children to eat first & $123(61.5)$ & $66(33)$ & $11(5.5)$ & 512 & 2.56 & 3 \\
\hline $\begin{array}{l}\text { Engaging in additional small-scale } \\
\text { productivity activities }\end{array}$ & $90(45)$ & 74 (37) & $36(18)$ & 454 & 2.27 & 4 \\
\hline Skipping meal within a day & $99(49.5)$ & $54(27)$ & $47(23.5)$ & 452 & 2.26 & 5 \\
\hline Buying food on credit & $92(46)$ & $68(34)$ & $40(20)$ & 452 & 2.26 & 6 \\
\hline Backyard livestock production & $63(31.5)$ & $83(41.5)$ & $54(27)$ & 409 & 2.05 & 7 \\
\hline Borrowing money to buy food & $66(33)$ & $69(34.5)$ & $65(32.5)$ & 401 & 2.01 & 8 \\
\hline Mortgaging and sales of domestic assets & $35(17.5)$ & $48(24)$ & $117(58.5)$ & 318 & 1.59 & 9 \\
\hline Eating wild fruits & $20(10)$ & $66(33)$ & $114(57)$ & 306 & 1.53 & 10 \\
\hline Eating once a day & $28(14)$ & $42(21)$ & $130(65)$ & 298 & 1.49 & 11 \\
\hline Selling labour power & $25(12.5)$ & $47(23.5)$ & $128(64)$ & 297 & 1.48 & 12 \\
\hline $\begin{array}{l}\text { Picking up left-over food at social } \\
\text { functions }\end{array}$ & 27 (13.5) & $19(9.5)$ & 154 (77) & 273 & 1.37 & 13 \\
\hline
\end{tabular}

Source: Survey data, 2020

$\mathrm{NB}$ : $\mathrm{A}=$ always, $\mathrm{O}=$ occasionally, $\mathrm{N}=$ never, $\mathrm{WS}=$ weighted score, $\mathrm{LM}=$ Likert mean and $\mathrm{R}=$ rank 


\section{Conclusion}

The outcome of this research revealed that most of the rural households were food insecure during COVID-19 pandemic. They consumed less the daily recommended calorie intake of $2260 \mathrm{kcal}$ per capita with a short fall of $39 \%$. It can be inferred from this study that COVID-19 posed a serious threat to the food availability and security among the rural households, especially households with larger size, which led to adoption of some coping strategies. The widely adopted coping strategies by rural households during COVID-19 pandemic were eating less expensive food, reducing rational consumption, allowing children to eat first, engaging in additional small-scale productivity activities, skipping meal within a day, buying food on credit and borrowing money to buy food.

To reduce the current level of food insecurity in the study area, this study recommends that governments and relevant organisations support the rural households to boost their food availability. Rural households' food availability can be boosted through provision of farm inputs and free food as palliative. Provision of farm input will, in turn, boost rural farmers income and improve their economic status. Rural education is also very important to reduce the high level of food insecurity. Through this, the rural households will be enlightened to practise modern family planning in order to have the number of children their resources can effectively cater for.

\section{References}

Agada, M. O., \& Igbokwe, E. M. (2015). Food Security and Coping Strategies among Ethnic Groups in North Central Nigeria. Developing Country Studies 4(8), 31-45.

Akanbi, O. S.-U., Oloruntola, D. S., Olatunji, S. O., \& Mukaila, R. (2020). Economic analysis of poultry egg production in kwara state, Nigeria. Journal of Economics and Allied Research, 4(3), 57-71.

Ali, M.S.S., Majika, A., Salman, D., (2017). Food Consumption and Production in Tempe Lake, South Sulawesi, Indonesia. J. Asian Rur. Stud. 1(1): 43-52

Babatunde, R. O., \& Qaim, M. (2010). Impact of Off-farm Income on Food Security and Nutrition in Nigeria By Impact of Off-farm Income on Food Security and Nutrition in Nigeria. Proceeding of Africa Association of Agricultural Economists, "Africa and the Global Food and Financial Crises", $19-23$ September, 2010, Cape Town, South. pp

Babatunde, R. O., Omotesho, O. A., \& Sholotan, O. S. (2007). Socio-Economics Characteristics and Food Security Status of Farming Households in Kwara State, North-Central Nigeria. Pakistan Journal of Nutrition, 6(1), 49-58.

Declaro-Ruedas, M.Y.A. (2019). Coping Strategies Adopted by Iraya-Mangyan Households During Food Insecurity in Abra, Occidental Mindoro, Philippines. J. Asian Rur. Stud. 3(1): $85-92$

De Sousa, A. (2020). Tracking COVID-19. Bloomberg News. Retrieved from https://www.bloomberg.com/graphics/2020-coronavirus-dash/

ENADEP 2014. Enugu State Agricultural Development Programme; Annual Report, pp 27. Published by Enugu State Government of Nigeria.

ENADEP 2016. Enugu State Agricultural Development Programme; Annual Report, pp 27. Published by Enugu State Government of Nigeria.

Matemilola, S. and Elegbede, I. (2017). The challenges of food security in Nigeria. Open Access Library Journal, 4: 1-22. https://doi.org/10.4236/oalib.1104185

Mukaila, R., Falola, A., \& Omotesho, O. A. (2020). Food security status: its drivers and coping strategies among vegetable farming households. Cercetări Agronomice În Moldova, 53(4), 414-425. https://doi.org/10.46909/cerce-2020-035

Mukaila, R., Obetta, A. E., Awoyelu, F. E., \& Jachinma, C. (2021). Marketing Analysis of 
Vegetables: The Case of Carrot and Cucumber Marketing in Enugu State, Nigeria. Turkish Journal of Agriculture - Food Science and Technology, 9(2), 346-351. https://doi.org/https://doi.org/10.24925/turjaf.v9i2.346-351.4000

National Bureau of Statistics (NBS) (2012). Federal Ministry of Agriculture and Rural Development Collaborative Survey on National Agriculture Sample Survey (NASS), 2010/2011Draft Report, May 2012.

Obasan, T. A., Okojie, L. O., \& Okuneye, P. A. (2017). DETERMINANTS OF RURAL HOUSEHOLDS' FOOD SECURITY IN OGUN ST ATE, NIGERIA. Conference Proceedings o/The 18' Annual National Conference of The Nigerian 1ssociation OfAgrirnltural · Economists Held Al Federal University of Agriculture, Abeokuta, Nigeria 16 - 19th October, 2017.

Obetta, A. E., Achike, A. I., Mukaila, R., \& Bala Taru. (2020). Economic analysis of marketing margin of banana and plantain in enugu state, Nigeria. African Journal of Agriculture and Food Science, 3(4), 52-62.

Obetta, A. E., Mukaila, R., Onah, O. G., \& Onyia, C. C. (2020). Challenges of Melon Processing Among Women Processors in Enugu-Ezike Agricultural Zone of Enugu State , Nigeria. Turkish Journal of Agriculture - Food Science and Technology, 8(11), 2421-2425. https://doi.org/https://doi.org/10.24925/turjaf.v8i11.2421-2425.3707

Omotesho, O. A., Adewumi, M. O., \& Ayinde, O. E. (2006). Determinants of Food Security Among The Rural Farming Households in Kwara State, Nigeria. African Journal of General Agriculture, 2(1), 7-15.

Opaluwa, H. I., Oyibo, F. O., \& Jimoh, F. A. (2018). Determinants of Food Security Among Farming Households in Akure North Local Government Area of Ondo State, Nigeria. 2(2), 164-172.

Oyebanjo, O., Ambali, O. I., \& Akerele, E. O. (2013). Determinants of food security status and incidence of food insecurity among rural farming households in Ijebu division of Ogun state Nigeria. Journal of Agricultural Science and Environment, 13, 92-103.

Soma, G. J. (2020). Communicating to children about the COVID-19 pandemic. Medical Journal, 13(2), 60-63.

Teddu, S., Ali, M.S.S., Salman, D. (2018). Food Production and Consumption Pattern at Coastal Area of Karampuang Island. J. Asian Rur. Stud. 2(2): 196-204

Vos, R., Martin, W., \& Laborde, D. (2020). As COVID-19 spreads, no major concern for global food security yet. Washington, DC: International Food Policy Research Institute [Blog post]. Retrieved from https://www.ifpri.org/blog/covid-19-spreads-no-major-concernglobal-food-security-yet

Zurayk, R. (2020). Pandemic and Food Security: A View from the Global South. Journal of Agriculture, Food Systems, and Community Development. https://doi.org/10.5304/jafscd.2020.093.014 